POLSKA AKADEMIA NAUK - ZAK

\begin{tabular}{lrrrrrrrr} 
A C T A & T H E R I O L O G I C A \\
Vol. v, 11 & & BIAŁOWIEżA & & 10. X. 1961 \\
\hline
\end{tabular}

Stanisława S I U D A \& Zofia S Z Y M A Ń S K A

\title{
Comparative Investigations of the Salivary Glands of Small Rodents
}

\author{
[With 9 figs. pl. VIII-IX] \\ I. INTRODUCTION
}

Badania porównawcze ślinianek drobnych gryzoni

Many research workers have investigated the problem of salivary glands from the morphological and histochemical point of view, and morphological papers on this subject were encountered even in the past century, including that of Garnie r (1899), who described the behaviour of the serous cells of the salivary glands of the rat when given pilocarpine. Cohoe (1907) investigated the submandibular salivary glands of the rabbit, in which he observed light cells - mucous, and dark cells - serous, containing granular matter. Loeventhal (1907) described the additional serous and mucous glands of the submandibular salivary gland of the hedgehog. In B e nsle y's (1908) work there is a note on the working methods used for histological research on salivary glands, and $\mathrm{S} \mathrm{c} \mathrm{h} \mathrm{a} \mathrm{f} \mathrm{f} \mathrm{e} \mathrm{r} \mathrm{(1908)} \mathrm{makes} \mathrm{some} \mathrm{intere-}$ sting remarks on the submandibular salivary glands of insectivores and the specific differences in the structure of these glands. A e berhard (1936) described the histology and histogenesis of the submandibular salivary glands of cats and dogs, Lacas s a g n e (1940) the sexual dimorphism in the submandibular salivary glands of the mouse, Hilla rp (1949) and Snel1 \& Garret (1948) the innervation of the salivary glands, while the role of the ducts of the salivary glands of different species of animals was described by Hill \& Bourne (1954).

More recent works on the salivary glands discuss the application of new histochemical methods aimed at discovering enzymatic activity and complicated chemical compositions such as polysaccharides, acid mucopolysac- 
charides, metachromatic substances and others. For instance, enzymes in the epithelium of the gland ducts were examined by 'M a rtin (1953) and by Hill, Ruth \& Bourne (1954). Acid mucopolysaccharides in the salvary glands were discovered by means of a colloidal solution of iron by Graumann (1958) Graumann \& Clauss (1958) and Geyer (1958). In Poland the histochemistry of the salivary glands of small manmals was investigated by the Słotwinski (Histochemical Symposiun, 1958), while the influence of castration on the morphological picture of the parotid salivary gland was investigated by $\mathrm{Dz}$ i er ż $\mathrm{kray}-\mathrm{R} \circ \mathrm{g}$ a $1 \mathrm{ska}$, Chodynicki \& Wiśniewski (1960).

Works are also encountered in literature on the differences in the structure of the salivary glands in different species of animals $(\mathrm{Sch}$ a f fer, 1908) and in individuals of the same species but kept on different diets (Carbohydrate or milk diet $-\mathrm{Schmidt}$, 1959). In connection with this the authoresses decided to make investigations of the salivary glands of four different species of rodents belonging to the family Muridae: - the white mouse, white rat, Microtus agrestis (Linnae us 1761) and Clethrionomys glareolus ( $\mathrm{Schreber} 1780$ ). The mouse, rat and bank vole are granivorous animals, and the field vole - graminivorous. The aim of the authoresses was to find out whether there are differences in the structure of the salivary glands of the above species, and if so, whether these are generic differences, or differences resulting from the different way of life and food of the animals.

\section{MATERIAL AND METHODS}

Forty males of white mice, white rats, and voles were used for investigation purposes. The M. agrestis and Clethrionomys glareolus came from the Białowieża Forest, and the white mice and rats were bred in the Institute. The salivary glands were fixed in formol-alcohol, Carnoy's fluid or Zenker's fluid. Paraffin microscopic sections $6 \mu$ thick were stained with: haematoxylin-eosine, Heidenhain's ferrous haematoxylin and by Heidenhain's Azan method. Colloidal solution of iron acc. to Müller, as modified by Graumann-Clauss was used to find acid mucopolysaccharides. Staining was also done with methyl green and pyronin acc. to Unny-Pappenheim. The P.A.S. method was applied and also combined staining with P.A.S. - iron (P e a r s e, 1957). Metachromatic substances were stained with toluidine blue, mucus - with mucicarmine. and Golgi's apparatus was found by the Āoyama silver method.

\section{OUR OWN INVESTIGATIONS}

Three kinds of salivary glands can be distinguished in mice, rats, field voles, and bank voles: the parotid, submandibular and sublingual salivary glands (Fig. 1). 
Salivary glands are paired and lie in the neck region just below the skin. Those nearest the centre are the submandibular salivary glands, which are yellowish in colour. The sublingual salivary glands, which are smaller than the submandibular, lie above the upper part and to the side of the latter. The parotid salivary glands lie the furthest to the side below the Loeventhal glands (L oeventhal, 1900), and are rose-coloured, irregular in shape, with an uneven surface. In each salivary gland the following sections may be distinguished - the terminal secretory sections and ducts consisting of insertions, P f l ü g e r's salivary ducts, interlobular and outlet ducts.

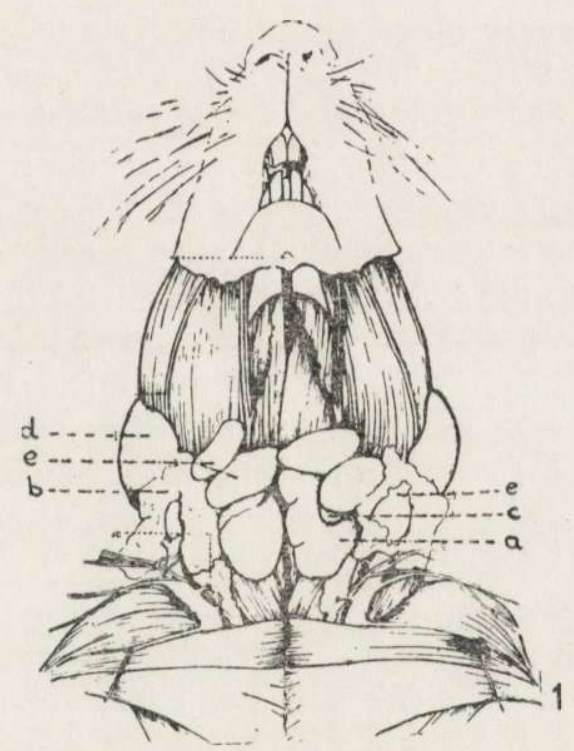

Fig. 1. Neck region of the rat: a) submandibular salivary gland, b) parotid salivary gland, c) sublingual salivary gland, d) Loeventhal's gland, e) lymphatic nodes. Acc. to Ferris E., 1949.

The parotid salivary gland exhibits certain differences in the species studied. In mice, rats and bank voles this is a homogenous gland of the serous type (Fig. 2, Pl. VIII). The cells are arranged in vesicles, and these in turn form lobes. The vesicles are fairly large and distinctly separated from each other. In places the boundaries of the cells, which are cone-shaped in the cross-section, can be seen. The cytoplasm of the cells is slightly alkali-absorbent, and spherical nuclei lie close to the base. After applying the Unna- 
Pappenheim method (methyl green - pyronin) the cells are filled with numerous pink granules and the surrounding band formed by the vesicles is an intense red. This phenomenon can be seen particulary clearly in the bank vole. The cytoplasm of the cells gives a reaction to P.A.S., a very weak reaction with colloidal iron, does not exhibit metachromasis nor stain with mucicarmine. The epithelium of the secretory ducts gives no reaction with either pyronin or with colloidal iron, is negative to P.A.S., with the exception of the insertion in which granular matter positive to P.A.S. can be observed. The Golgi apparatus lies in the apical part of the cell.

The parotid salivary gland of the field vole (Fig. 3, Pl. VIII) has a slightly different structure. It is not a homogenous gland, but consists of lobes of non-uniform structure. Part of the lobes contain only the serous terminal secretory sections (similarly to the mouse, rat and bank vole), and adjacent to them are lobes formed of modified serous cells resembling mucous cells - pseudo-serous cells and lobes of mixed structure. The vesicles formed from pseudo-serous cells are larger than the serous vesicles, while the boundaries of the cells cannot be seen. These cells exhibit certain features in common with mucous cells, but in certain points are similar to serous cells. Like mucous cells, they have flattened nuclei lying close to the base, they give a reaction, although weak, with mucicarmine, and their granular matter is very strongly beta-meta-chromatic and stains blue with Azan. These cells, however, stain with pyronin in the same way as serous cells, that is, intensely. Reaction with colloidal iron and reaction to P.A.S. are also very weak - and thus similar to that of serous cells.

Secreting ducts in the parotid salivary gland of the field vole occur in smaller numbers than in those of the mouse, rat and bank vole, and the reaction given by their cells are similar to the reactions given by the cells of parotid salivary gland ducts of the remaining animals.

The sublingual salivary gland (Figs. 4-5, Pl. VIII, and 6, Pl. IX) in all the species studied by us is of similar appearance. The terminal secretory sections are typically mucous sections and occur in the form of canals. The cytoplasm of the cells is vacuolized, flattened nuclei lie in the basal part of the cell (Fig. 4). Here and there on these canals there are Gianuzzi half-moons formed of 
serous cells, giving a histochemical reaction typical of these cells (Fig. 5). The cells of the terminal mucous sections stain intensely with mucicarmine and colloidal iron, and give a strong reaction to P.A.S., (Fig. 6), when stained with a combination of iron - P.A.S., blue staining is visible of the acid muco-polysaccharides and purple-red staining of substances positive to P.A.S. Mucous cells give distinct metachromasis with blue toluidine, but are not stained with pyronin (Fig. 5), the Golgi apparatus lies mainly in the basal part of the cell. The epithelium of the secretory ducts does not give positive results with the histochemical reactions applied.

The secretory vesicles of the submandibular salivary gland of the mouse, rat and bank vole (Fig. 7,8 ) consist of cells which when stained with haematoxylin-eosine have the typical appearance of serous elements. The cytoplasm of these cells is slightly alkaliabsorbent, the nuclei are round. In addition these cells, like the serous cells, give a moderately strong reaction to P.A.S., and when stained with pyronin exhibit numerous pink granular substances, and a distinct red edge at the base of the cells. Empty vacuoles, probably lixiviated drops of fat, are often encountered in the cytoplasm of these cells. When certain histochemical methods are used, the reactions given by these cells are, however, different from the reactions given by serous cells: the cytoplasm of the cells stains with mucicarmine (slightly), gives a distinct reaction with colloidal iron and staining with blue toluidine is slightly metachromatic. It must be supposed, therefore, that these are serous cells which also produce a mucous secretion - i. e. muco-serous cells.

In the field vole the terminal secretory sections of the submandibular salivary gland has the same structure as the terminal secretory sections of the parotid salivary gland: they consist of serous and pseudo-serous cells. The latter have flattened, shifted nuclei, contain granules which stain metachromatically with blue toluidine and stain with mucicarmine. They are not, however, typical mucous cells, as they give only a weak reaction to P.A.S. and none with colloidal iron, and stain with pyronin like serous cells.

Certain elements, not encountered in other salivary glands (Figs. $7,8,9$ ) are deserving of special attention in the submandibular salivary gland in all of the species examined. These are numerous (in the case of mice extremely numerous) sections lying between the insertion and Pflüger's salivary duct. They do not 
possess the structure typical of the secretory duct, and do not resemble either an insertion or Pflüger's duct. They are elements with a large diameter, but very narrow lumen, lined with high cells, the base of which is darker when the cells are stained with haematoxylin-eosine. The cytoplasm of the cells is slightly acidabsorbent and round or flattened nuclei lie in the basal part of the cell. In the cytoplasm above the nucleus there is a large amount of granular substance which stains with ferrous haematoxylin, with azocarmine and gives a positive reaction to protein acc. to Millon. These granular substances often completely fill the whole apical section of the cell. The Golgi apparatus is situated in the basal part of the cell near the nucleus as in the case of secretory cells. Cells of this section are P.A.S. positive, in the case of the field vole only the top part of the cells gives a P.A.S. positive reaction, while with mice, rats and bank vole a positive reaction is visible in the whole of the cytoplasm. The above sections do not give a reaction with colloidal iron, do not stain metachromatically and do not stain with mucicarmine. In the basal part of the cells there are small granules which stain with pyronin.

The cells of the ducts of the submandibular salivary gland do not stain with colloidal iron, although when stained with combined iron - P.A.S., their blue colouring is visible. The cells of the insertion have granular substance very strongly P.A.S. positive. The Golgi apparatus in the insertions, Pflüger's ducts and interlobular ducts is situated in the upper part of the cell above the nucleus and is situated on the same level in all the cells.

\section{RESULTS AND DISCUSSION}

As will be seen from the above, only the sublingual salivary gland - a purely mucous gland - exhibits a uniform structure in all the species examined, while differences are visible in the parotid and submandibular salivary glands. The parotid salivary gland of the rat, mouse and bank vole is a typical serous gland, while in the field vole this gland contains three kinds of lobe, purely serous, lobes formed of modified serous cells resembling mucous cells, which have been termed by the authoresses pseudoserous, and mixed lobes. The bank vole although generically related to the field vole, has a purely serous parotid salivary gland, almost identical in structure with that of mice and rats, but different from 
that of the field vole. As these three species: mouse, rat and bank vole eat the same kind of food - grain, while the field vole is a graminivorous animal it may be assumed that the structure of the parotid salivary glands in these animals depends on the type of food eaten, and not on the fact that systematically they belong to the same family, and that in animals eating dry foods (grain) this gland contains only serous cells, that is, cells producing a fluid secretion. Brieger (1939) and Stomont (1928) (cited after Schmidt, 1959) also noticed the dependence of the structure of the salivary gland on the type of food. They observed in rats with a dry carbohydrate diet an increase in the number of serous elements producing a fluid serous secretion, while in the case of a juicy diet the salivary glands secreted more mucus. Specific differences in the structure of salivary glands probably occur in animals farther apart systematically.

A similar dependence can be observed in the submandibular salivary gland also, which in the field vole, a graminivorous animal, consists, like the parotid salivary gland, of two kinds of cells serous and pseudo-serous, which in the mouse, rat and bank vole - animals eating dry food - consist of uniform cells resembling serous cells in appearance. They, like serous cells, are slightly alkali-absorbent, stain strongly with pyronin, have round nuclei and simultaneously give a weak reaction for mucus. It must therefore be concluded that these are probably serous cells also producing mucus - muco-serous cells. The authoresses did not, however, observe the purely mucous cells in this gland to which $\mathrm{Schmidt}$ refers (1959). From the above it appears that the submandibular salivary gland in the animals examined, like the parotid salivary gland, also exhibits differences in structure between the glands of mice, rats and bank voles on the one hand, and the field vole on the other.

Apart from the differences occurring in the structure of secretory sections of the salivary glands of different species of animals depending on the type of food eaten, the presence in the submandibular gland of certain elements, which the authoresses have called granular sections, is worthy of emphasis. These are duct-like forms with a large diameter but very narrow lumen, formed of high cells of slightly acid-absorbent cytoplasm. The round nuclei are light in colour and are similar to the nuclei of the ducts. Nuclei 
are frequently observed in the stage of caryokinetic fission. Golgi apparatus is usually situated at the base of the cell. Numerous granular substances which stain with ferrous haematoxylin and azocarmine, can be seen in the cytoplasm. These elements have features characteristic both of the conducting canals and secretory sections. Their situation and shape would seem to indicate that these are ducts, while the presence of granular matter, the position of Golgi's apparatus and the positive reaction to P.A.S. indicate their secretory character.

Schmidt (1959) observed similar elements in the rat, while W imsatt (1956) who investigated the salivary glands of fruiteating bats, considers these forms as mucous secretory sections producing a serous secretion, and calls them pseudomucous.

\section{CONCLUSIONS}

1. Sublingual salivary glands in all the species of animals examined: mouse, rat, field and bank voles are typical mucous glands with a small number of serous cells (half-moons).

2. The secretory part of the parotid salivary glands of mice, rats and bank voles - animals eating dry food, grain - consists entirely of serous cells, while in the field vole, a graminivorous animal - it consists of two types of cell - serous and pseudo-serous.

3 . The secretory units of the submandibular salivary gland of mice, rats and bank voles are formed from cells of a uniform type: muco-serous, while in the field vole, similarly to the parotid salivary gland, they are formed of two types of cells: serous and pseudo-serous.

4. The difference in the structure of the terminal secretory sections of the parotid and submandibular salivary glands of the mouse, rat and bank vole on the one hand, and of the field vole on the other, probably results from the difference between the foods eaten by these animals.

5. No specific differences could be found in the structure of the salivary glands in the animals examined.

6. The submandibular salivary gland of the animals examined contains a granular section not found in other types of salivary glands. 
Acnowledgements: It is our pleasant duty to express our gratitude to Doc. Dr Helena Lewińska - Head of the Department of Histology and Embryology of the Białystok Medical School, for her help and guidance during the preparation of this work.

We should also like to thank Professor Dr August Dehnel-Head of the Mammals Research Institute of the Polish Academy of Sciences at Bialowieża, for his criticism of our work during its preparation and for placing at our disposal the animals used for this work.

\section{REFERENCES}

1. A e berhardt, F., 1936: Beitrage zur Histologie und Histogenese der Unterkieferdrüse ( $g l$. mandibularis) von Hund und Katze. Ztschr. Mikr. Anat. Forsch., 40: 558-585.

2. B ens le y, R. R., 1908: Observation on the salivary glands of Mammals. Anat. Rec., 5: 105-107.

3. B e rtrand, J., 1955: Les cholinestérases dans les glandes salivaires. C. R. Biol., 149: 2267-2269.

4. Cohoe, B. A., 1908: The finer structure of the glandula submaxillaris of the Rabbit. Am. J. Anat., 6: 167-190.

5. Dzi erżykray-Rogalska, I., Chodynicki, St. \& Wiśniewski, L., 1960: Wpływ usunięcia jąder na śliniankę przyuszną i gruczoł Leoventhala. Endokrynologia Polska, 11: 105-114.

6. F a r ris, E. J., 1949: The rat in laboratory investigation. J. B. Lippincott Company, London.

7. Garnier, Ch., 1899: De quelques details cytologiques concernant les elements sereux des glandes salivaires du rat, Bibl. Anat., 7: 217-224.

8. Ge ye r, G., 1958: Vergleichende topochemische Untersuchungen mit der Reaktion nach Hale und ihrere Modifikation von G. Müller an einigen Organen und Geweben der weissen Ratte. Acta Histochemica, 5: $62-78$.

9. Graumann, W., 1958: Vergleichende Untersuchungen zur Frage der Spezifität verschiedener Modifikationen der Polysaccharid-Eisenreaktion. Acta Histochemica, 5: 49-61.

10. Graumann, W. \& Clauss, W., 1958: Weitere Untersuchungen zur Spezifität der Histochemischen Polysaccharid-Eisenreaktion. Acta Histochemica, $6: 1-7$.

11. Hill, C. R. \& Bourne, G. H., 1954: Histochemistry and cytology of the salivary gland duct cells. Acta Anat., 20: 116-128.

12. Hillarp Nils-Ake, 1949: Some critical remarks on the problem of the double innervation of salivary gland cells. Acta Anat., 8: 190.

13. Lac a s agne, A., 1940: Dimorphisme sexuel de la glande sous-maxillaire chez la souris. C. R. Soc. Biol., 133: 180-181.

14. Loeventhal, N., 1907: Note sur la glande sous-maxillaire du Herrison. Bibl. Anat., 16: 167-171. 
15. M a rtin, B. F., 1953: Lipase in gland duct epithelium and in mucus secreting cells. Nature, 172: 1048-1049, London.

16. Pearse, E. A. G., 1958: Histochemia teoretyczna i stosowana. P.Z.W.L., Warszawa.

17. $\mathrm{Sch}$ affer, J., 1908: Zur Histologie der Unterkieferspeicheldrüsen bei Insectivoren. Ztschr. Wiss. Zool., 98: 1-27.

18. Schmidt, E.S.G., 1959: Der Einfluss der Winterschlafes, des Megaphenschlafes, der Hungerns und Verschiedener Kostarten auf die Speicheldrüsen von Myoxus, Erinaceus europaeus Mus und Rattus. Ztschr. Zellf. Mikr. Anat., 50: 143-182.

19. Snel1, R. S. \& Garret, J. R., 1958: The effect of postganglionic sympathectomy on the structure of the submandibular and major sublingual salivary glands of the Rat. Ztschr. Zellf. Mikr. Anat., 48: $639-652$.

20. W i m s a t t, W. A., 1956: Histological and histochemical observations on the parotid, submaxillary, and sublingual glands of the tropical american fruit bat, Artibeus jamaicensis, Journ. Morph., 99: 169-209.

Białystok Medical School,

Dept. of Histology and Embriology,

Białystok, Kilińskiego 1.

\section{STRESZCZENIE}

Autorki przebadały ślinianki czterech gatunków gryzoni, należących do dwóch różnych podrodzin: Murinae (mysz biała, szezur biały) oraz Microtinae (polnik bury i nornica ruda). Niniejsza praca jest próbą wykrycia różnic w budowie ślinianek oraz ustalenia ich przyczyn.

Slinianki utrwalono w formol-alkoholu, płynie Carnoy'a i płynie Zenkera; zatopiono w parafinie. Skrawki $6 \mu$ barwiono hemotoksyliną-eozyną, hematoksyliną żelazistą Heidenhaina, żelazem koloidalnym wg Mü̈llera w modyfikacji Graumann - Clausa, mucikarminem, błękitem toluidyny, zielenią metylową i pyroniną wg. Unny-Pappenheima oraz stosowano metodę srebrową Aoyamo, metodę Azan - Heidenhaina, metodę P.A.S. i łączne barwienie P.A.S. - żelazo.

Na podstawie przeprowadzonych badań autorki stwierdziły, że ślinianka podjęzykowa wszystkich badanych zwierząt jest gruczołem mieszanym z przewagą elementów śluzowych.

Część wydzielnicza ślinianki przyusznej myszy białej, szezura białego i nornicy rudej (zwierząt żywiących się pokarmem suchym) składa się wyłącznie $\mathrm{z}$ komórek surowiczych. U polnika natomiast (zwierzę trawożerne) składa się z dwóch typów komórek: surowiczych i pseudosurowiczych.

Elementy wydzielnicze ślinianki podszczękowej w/w zwierząt są również odmiennie zbudowane: u myszy białej, szczura białego i nornicy rudej składającej się z jednakowych komórek surowiczo-śluzowych, zaś u polnika z komórek surowiczych i pseudosurowiczych. Należy podkreślić, że ślinian- 
ka podszczękowa badanych zwierząt zawiera niespotykany w innych typach ślinianek odcinek ziarnisty. Jest to odcinek leżący między wstawką a cewką ślinową, zbudowany $\mathrm{z}$ dużych komórek, które w szczytowej części zawierają ziarnistości barwiące się azokarminem i hematoksyliną żelazistą. Odcinek ten morfologicznie przypomina cewkę śluzową, nie daje jednak żadnych reakcji na śluz.

Różnice w budowie ślinianki podszczękowej i przyusznej myszy białej, szczura białego i nornicy rudej z jednej strony, a polnika burego $z$ drugiej pozwalają przypuszczać, że ich źródłem jest różny sposób odżywiania się przebadanych zwierząt.

\section{EXPLANATION OF PLATES}

\section{PLATE VIII}

Fig. 2. Parotid salivary gland of the rat. Staining with methyl green and pyronin. Magnified 470 times.

Fig. 3. Parotid salivary gland of the field vole, pseudo-serous cells visible. Staining with haematoxylin-eosine. Magnified 570 times.

Fig. 4. Sublingual salivary gland of the rat, stained with haematoxylin-eosine. Magnified 470 times.

Fig. 5. Sublingual salivary gland of the mouse, stained with pyronin. Gianuzzi half-moons formed of serous cells visible. Magnified 470 times.

\section{PLATE IX}

Fig. 6. Sublingual salivary gland of the mouse. Mucous cells are positive to P.A.S. Magnified 440 times.

Fig. 7. Submandibular salivary gland of the rat stained with haematoxylineosine. Muco-serous vesicles visible. Magnified 570 times.

Fig. 8. Submandibular salivary gland of rat. Granular substances in granular ducts stained with ferrous haematoxylin. Magnified 470 times.

Fig. 9. Submandibular salivary gland of the rat stained by P.A.S. method. Magnified 440 times.

Microphotographs by K. Odyniec.

Państwowe Wydawnictwo Naukowe * Warszawa $1961 \mathrm{r}$.

Nakład 1400 egz. Ark. wyd. 0,85. Maszynopis otrzym. 31. VII. 1961 r.

Podpisano do druku 29. IX. 1961 r. Druk ukończ. 15. X. 1961 r.

Papier druk sat. kl. III. 80 gr. Format B-1

Białostockie Zakłady Graficzne. Zam. 3383 * B-2 * Cena 5 zl. 

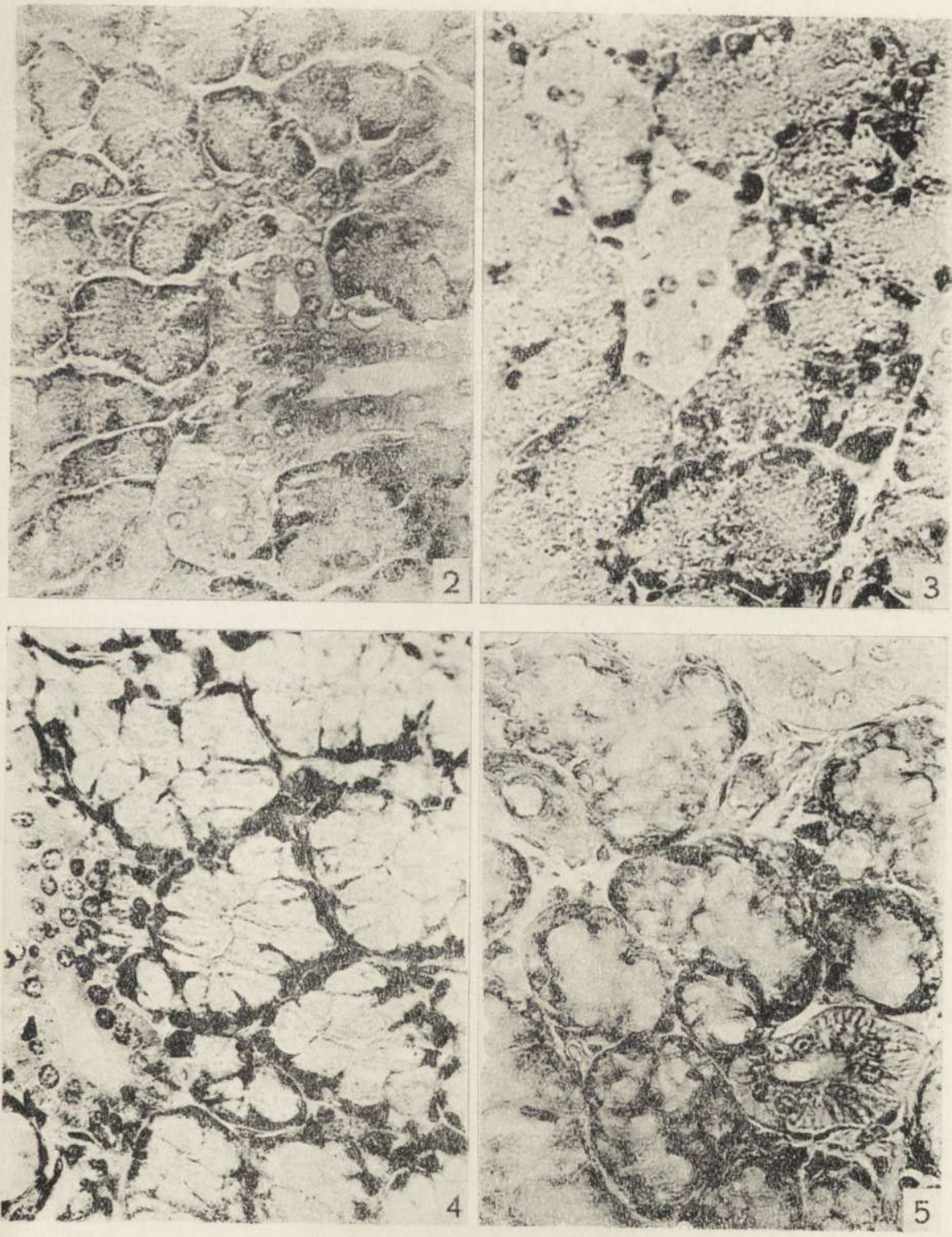

S. Siuda \& Z. Szymańska

K. Odyniec phot. 

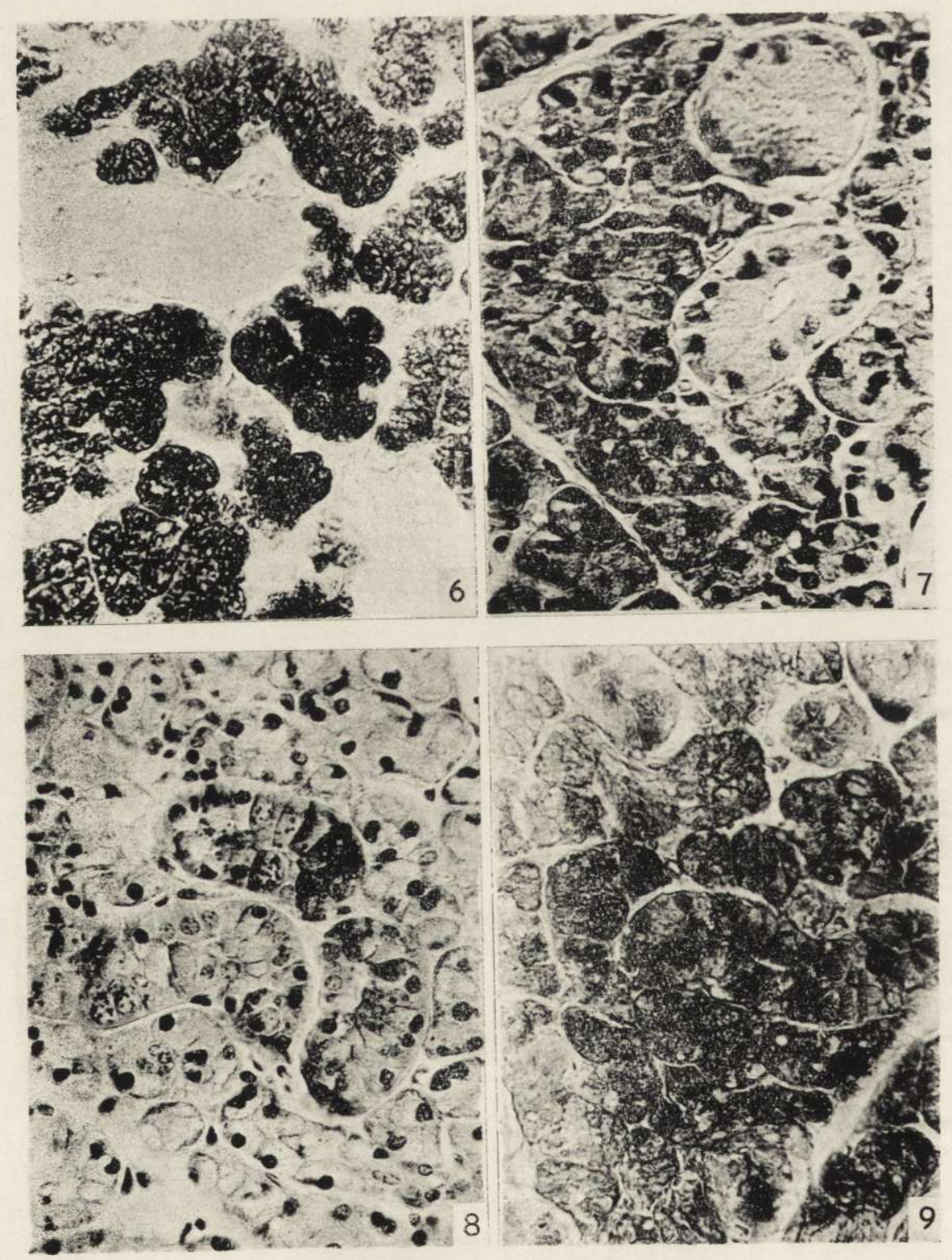

S. Siuda \& Z. Szymańsk:

K. Odyniec phot.

BIBLIOTEKA

Instytutu Biologii Ssaków

Polskiej Akademii Nauk

$\mathrm{NrCz} \cdot \mathbf{4 0 . 2}$ 